\title{
The Impact of Data-driven Learning based Program on Developing Student Teachers' Lexico- grammatical Performance Skills in EFL Writing
}

\section{Heba Moustafa Elmansi}

Assistant lecturer at Department of Curriculum \& Instruction (TEFL)Faculty of Education, Damietta University

\section{Dr. El-Sayed Mohamad Dadour}

Professor of Curriculum \& Instruction(EFL) Faculty of Education President of Damietta University

\section{Dr. Aly AbdelSamea Qoura}

Professor of Curriculum \& Instruction(EFL) Faculty of Education Mansoura University

\section{Dr. Taghreed Ali Hamada}

Lecturer of Curriculum \& Instruction (EFL) Faculty of Education

\section{Abstract}

7 The research aimed at investigating the impact of data-driven learning based program on developing student teachers' lexicogrammatical performance skills in EFL writing. The participants of the study were sixty (60) second year general section student teachers' in Damietta University, Faculty of Education, Egypt. The research adopted the quasiexperimental research design. So, there were two groups: an experimental group $(n=30)$ and a control one $(n=30)$. To collect data, the researcher used multiple instruments: a lexico-grammatical performance skills checklist, an EFL writing skills checklist, computer and internet skills questionnaire, pre-posttest of lexico-grammatical performance skills and an EFL writing test. The researcher taught the experimental group through a program based on DDL while the control group was taught through the regular method of teaching. The results of the research revealed that there was a statistically significant difference between the mean scores of the experimental group and the control group in the lexico-grammatical performance skills and EFL 
writing skills in favor of the experimental group. The effect size of the program based on DDL was found to be high. The research recommends using data-driven learning based a program as a technique in teaching EFL skills and as a training method in professional development programs of EFL teachers.

Key Words: Data-driven Learning (DDL), Lexico-grammatical, EFL Writing.

\section{Introduction and background}

English is an international language used for communication with others. It contains four skills listening, speaking, reading and writing. There are also three parts in language vocabulary, grammar, and pronunciation should be learnt. Those parts are very important for supporting the English language skills in use especially lexicogrammatical performance skills. Perfectionistic of those parts are reflected on students' writing skills automatically.

Lexico-grammatical theory maintained that language teaching should start from lexis and their core meanings and the most typical collocations in language teaching and learning. Special attention should be paid to that most frequently occurring high-frequency lexis. In this theory, the meaning of word depends on their surrounding lexical items and frequent semantic selective tendency, and the context of the words meaning is constructed by highlighting word's collocation, colligation, semantic preference and semantic prosody. Therefore, acquiring lexico-grammatical performance skills help students to transfer messages, letters and knowledge through writing (Aş1k et al 2016\& Abu Shawish, 2009).

Learning to write in English as a foreign language has been an essential professional educational issue that serves various educational purposes and meets certain learning 
needs upon which the foreign language learners' progress depends (Al-Mansour \& Al Shorman, 2014). EFL writing plays an important role in two respects: First, it motivates students' thinking, organizing ideas, developing their ability to summarize, analyze and criticize .Second; it strengthens students' learning, thinking and reflecting on the English language (Rao, 2007; Bruning \&Horn, 2000).

Although lexico-grammatical performance skills play an important role in learning and teaching English in general and in EFL writing skills especially, it has not received careful attention. Hence, lack of lexico-grammatical contributes to writing difficulty for foreign language learners. Many studies have shown many problems in English writing such as (Khamis, 2019; Megaiab, 2014\& Al-Khairy, 2013; Keong \& Mussa 2015; Bahloul, 2007 ) stated that students' writing difficulties comes from lack of lexical items, grammar, spelling and punctuations errors, illogical sequence and confused on supporting ideas.

Lexical acquisition and knowledge in language teaching has increased, and our understanding of the issues involved in learning new words has deepened. Hence, lexical knowledge and learning becomes a lot more than learning the definition of a word. Metalinguistic awareness includes not only knowing a word dictionary definition, but also includes knowing the word's spelling, morphology, parts of speech, pronunciation, variant meanings, collocations, specific uses, and register related contexts of use (Nation, 2001 \& Koda, 2000). In addition to these, Flowerdew (2009) mentions colligation, semantic preference, and semantic prosody. 
On the other hand, instructors and supervisors still misunderstand the essence of the lexical items in the writing process .Many of them use traditional approaches based on memorization and drilling (Mostafa et al 2019 \& Mourtaga, 2010). Therefore, it is necessary to use modern strategies and approaches to keep up with the age of internet, information, technology, globalization and Corona-Virus. Data-driven learning can offer valuable insights for many of these aspects of knowing a word, particularly because we now understand that these issues are affected by the vocabulary word as well as the surrounding context.

The incorporation of discovery learning and the contemporary revolution of corpus based teaching, Tim John (1991: 2) suggested "Data-Driven Learning (DDL)" as an approach to teaching and learning lexico-grammatical performance skills. In DDL, the focus was shifted from deductive to inductive learning, noticing and consciousness-raising. DDL was taken through mediational access tool called linguistic corpus in the form of concordance citations that lead to key word on context as language input and self-discovery of lexico-grammatical by learners (Guan, 2013). Whereas traditional language learning materials tended to separate grammar and lexis, DDL fosters a more lexico-grammatical approach. This is facilitated by the use of a concordancer to retrieve commonly-occurring lexico-grammatical patterns for a search item.

Data driven learning allows teachers and students to study naturally occurring language for grammatical patterns, word usage, semantic and pragmatic features, and textual discourse (L, Flowerdew, 2009). Additionally, 
authentic language allows for language topics that otherwise might not occur in a textbook or from the examples created in teachers' minds, to be used in vocabulary and grammar discussions. It has traditionally focused on concordance lines, or incomplete sentences that focus on a common word, but new research and corpora have also used lines of texts with expanded context to increase learning possibilities (Boulton, 2009b\& Davies, 2008).

Chambers (2010) mentioned that DDL contains two types that refer to Hybrid Learning, hands-on DDL (computer-based DDL) which corresponds to direct corpus consultation and hands-off DDL (paper-based DDL) which is equivalent to indirect corpus consultation. Corpora allow access to authentic data; they reveal knowledge about the language that is not intuitive and show frequency patterns of words and grammar constructions (J. Flowerdew 2009).

\section{Literature Review}

Literature review, here, includes studies related to DDL approach and EFL writing and DDL and lexicogrammatical performance skills.

\section{Studies Related to Data-driven Learning and EFL writing}

The effect of DDL on writing is tackled from a variety of perspectives including errors correction, enhancement of fluency, complexity and particular tasks of writing. The majority of the empirical studies that have been conducted on issues of DDL and writing tasks agreed that the DDL approach has positive effects on the overall improvement of writing. The most prominent studies that examined the effect of DDL on EFL writing include Mao et al (2018); 
Qoura (2018); Ali (2016); Luo (2016); Sepehri (2015); Luo and Lia (2015); Yoon and Jo (2014) \& Gilmore (2009). Results of these studies showed certain theoretical guidance to the improvement of the EFL writing level of college students due to DDL.

\section{Studies Related to Data-driven Learning and Lexico- grammatical Performance Skills}

Lexical Grammar Theory is an important theoretical contribution for language study. Sinclair (2009) believed that a description of English cannot divide the language into two separate components, lexis and grammar, since grammatical features are decided by lexis and all lexical elements can have grammatical patterns. He observed that lexical meaning and grammatical meaning make up the word meaning as neither can exist without the other and many uses of words and phrases show a tendency to cooccur with certain grammatical choices.

There have been a number of studies on vocabulary, collocations and grammar development through the use of DDL in the two recent decades. Most studies have aimed to investigate the effects of DDL on learners' lexicogrammatical performance skills (Vyatkina, 2016; Mizumoto \& Chujo, 2016; Ucar \& Yükselir, 2015; Yunus \& Awab, 2014; Huang, 2014; Liu \& Jiang, 2009; Varley, 2009; Coxhead \& Byrd, 2007). The results showed that both DDL types were effective for learners, and overall learner proficiency increased.

\section{Statement of the problem}

In light of the previous studies, the pilot studies results and the researcher's experience in teaching student teachers, the problem of the study is that EFL student 
teachers' have limited lexico-grammatical performance skills. Moreover, they have difficulties acquiring the language or expressing themselves in a clear, correct and comprehensible manner. These problems may be due to the traditional methods of teaching lexico-grammatical performance skills in EFL classroom where students have a passive learning role. Therefore, the present research is an attempt to solve this problem through using data-driven learning and testing its effectiveness in improving EFL student teachers' lexico-grammatical performance skills.

\section{Research Questions}

The present research attempted to answer the following main question:

"How can data-driven learning based program contribute to develop second section student teachers' lexicogrammatical performance skills in EFL writing?"

The main question leads to the following sub questions:

- What are the lexical skills required for the second section student teachers' at the faculty of Education?

- What are the grammatical skills required for the second section student teachers' at the faculty of Education?

- What are the EFL writing skills required for the second section student teachers' at the faculty of Education?

- What are the features of the proposed data-driven learning based a program?

- To what extent can data-driven learning based a program develop second section student teachers' lexicogrammatical performance skills? 
- To what extent can data-driven learning based a program develop second section student teachers' EFL writing skills?

- What is the impact of using data-driven learning based a program for developing student teachers' lexicogrammatical performance skills on the development of student teachers' performance in the EFL writing skills?

\section{Purpose of the Research}

The present research aims at

- Investigating the impact of using data-driven learning in improving the lexico-grammatical performance skills in the EFL writing of the second section student teachers' at the Faculty of Education.

- Raising students' and researchers' awareness of using innovative methods in teaching lexico-grammatical performance skills in EFL writing.

\section{Significance of the Research}

The significance of this research comes through these points:

- Help specialists in organizing an effective teaching learning environment through using data-driven learning approach.

- It helps syllabus designers to modify, organize, and enrich English language curricula with activities based on applying data-driven learning.

- Provide a teacher guide of how to teach by using computer based on DDL and paper based on DDL to 
apply Hybrid Learning to improve lexico-grammatical performance skills in EFL writing.

\section{Participants of the Research}

A group of 60 second year general stage student teachers' were purposively selected from Damietta University, Faculty of Education, English department in New-Damietta in the academic year 2020/2021. The study targeted selected participants that have computer and internet skills. Students' age ranged from 20 to 21 years old. The participants of this research constituted a homogeneous group in terms of their schooling and English language proficiency. This number of participants was divided equally into two groups. The first group of 30 students comprised the experimental group and received data-driven learning based a program. The other group of 30 students served as the control group and received the regular teaching methods course.

\section{Design of the Research}

The design adopted in this research is quasiexperimental design (pretest-posttest). Two groups participated in this research. The first group represented as the experimental group and the second group represented as the control group.

\section{Hypotheses of the Research}

The research aimed at testing the following hypotheses:

- There is a statistically significant difference at $\leq(0.05)$ level between the mean score of the experimental group 
and that of the control group on the post administration of the lexical performance skills test in favor of the experimental group.

- There is a statistically significant difference at $\leq(0.05)$ level between the mean score of students of the experimental group on the pre and post lexical performance skills test in favor of the post test.

- There is a statistically significant difference at $\leq(0.05)$ level between the mean score of experimental group and that of control group on the post administration of the grammatical performance skills test in favor of the experimental group.

- There is a statistically significant difference at $\leq(0.05)$ level between the mean score of students of the experimental group on the pre and post grammatical performance skills test in favor of the post test.

- There is a statistically significant difference at $\leq(0.05)$ level between the mean score of experimental group and that of control group on the post administration of the EFL writing test in favor of the experimental group.

- There is a statistically significant difference at $\leq(0.05)$ level between the mean score of students of the experimental group on the pre and post EFL writing test in favor of the post test.

- Using DDL based program achieves effect size at $(\geq$ 0.14) level for improving student teachers' lexicogrammatical performance skills in EFL writing. 
- Developing lexico-grammatical performance skills has an impact on the development of EFL writing performance of the experimental group students.

\section{Instruments and materials of the research}

The researcher made use of the following instruments and materials:

- A Program based on Data-driven Learning (Designed by the researcher).

- A Lexical Skills Checklist submitted to a panel of jury to determine its validity and the appropriateness of the skills needed for second year general section student teachers' (Designed by the researcher).

- A Grammar Skills Checklist submitted to a panel of jury to determine its validity and the appropriateness of the skills needed for second year general section student teachers' (Designed by the researcher).

- A Lexical pre-posttest to assess students' lexical performance skills (Designed by the researcher).

- A Grammar pre-posttest to assess students' lexical performance skills (Designed by the researcher).

- An EFL Writing Skills Checklist Skills submitted to a panel of jury to determine its validity and the appropriateness of the skills needed for second year general section student teachers' (Designed by the researcher).

- An EFL Writing Pre-posttest to assess students' writing skills (Designed by the researcher). 
- An EFL Writing Rubric to score students' responses to the EFL writing skills test (Designed by the researcher).

\section{Delimitations of the Research}

The current study was delimited to:

- Second year general section student teachers in Damietta University, Faculty of Education, English department in the academic year 2020/2021. The participants were chosen by a Computer and Internet Skills Questionnaire.

- A limited duration for implementing the program based on Data-driven Learning (A university semester, i.e., nearly 2 months).

- Fourteen sessions designed by the researcher according to the program based on DDL and each session included three lessons.

- Some lexico-grammatical performance skills and EFL writing skills required for second year general section student teachers.

\section{Results of the Study}

Results of the study are presented in terms of the study hypotheses.

\section{Results of hypothesis 1:}

The first hypothesis stated that "there is a statistically significant difference at $\leq(0.05)$ level between the mean score of the experimental group and that of the control group on the post administration of the lexical test in favor of the experimental group". The researcher used Independent samples t-test to verify this hypothesis. Table (1) shows the results: 
JRCIET

Vol. 7, No. 3

July 2021

Table (1): Comparing the Performance of the Experimental and the

Control Group on the pre-post administration of the lexical test

\begin{tabular}{|c|c|c|c|c|c|c|}
\hline \multirow{2}{*}{ Lexical Skills } & \multirow{2}{*}{ Study groups } & \multirow{2}{*}{ Mean } & \multirow{2}{*}{ SD } & \multicolumn{3}{|c|}{ t-test } \\
\hline & & & & $\mathbf{t}$ & DF & P-value \\
\hline \multirow{2}{*}{ Skill1 } & Experimental group & 4.57 & 0.50 & \multirow[b]{2}{*}{10.0} & \multirow{2}{*}{58} & \multirow{2}{*}{0.001} \\
\hline & Control group & 2.27 & 0.58 & & & \\
\hline \multirow{2}{*}{ Skill2 } & Experimental group & 9.03 & 0.76 & \multirow[b]{2}{*}{24.40} & \multirow{2}{*}{58} & \multirow{2}{*}{0.001} \\
\hline & Control group & 4.70 & 0.60 & & & \\
\hline \multirow{2}{*}{ Skill3 } & Experimental group & 4.60 & 0.50 & \multirow{2}{*}{14.65} & \multirow{2}{*}{58} & \multirow{2}{*}{0.001} \\
\hline & Control group & 2.13 & 0.78 & & & \\
\hline \multirow{2}{*}{ Skill4 } & Experimental group & 4.33 & 0.66 & \multirow{2}{*}{12.06} & \multirow{2}{*}{58} & \multirow{2}{*}{0.001} \\
\hline & Control group & 2.03 & 0.81 & & & \\
\hline \multirow{2}{*}{ Skill5 } & Experimental group & 1.70 & 0.47 & \multirow{2}{*}{5.03} & \multirow{2}{*}{58} & \multirow{2}{*}{0.001} \\
\hline & Control group & 1.03 & 0.56 & & & \\
\hline \multirow{2}{*}{ Skill6 } & Experimental group & 4.47 & 0.68 & \multirow{2}{*}{12.29} & \multirow{2}{*}{58} & \multirow{2}{*}{0.001} \\
\hline & Control group & 1.87 & 0.94 & & & \\
\hline \multirow{2}{*}{ Skill7 } & Experimental group & 4.23 & 0.82 & \multirow{2}{*}{10.04} & \multirow{2}{*}{58} & \multirow{2}{*}{0.001} \\
\hline & Control group & 1.97 & 0.93 & & & \\
\hline \multirow{2}{*}{ Skill8 } & Experimental group & 4.37 & 0.61 & & & \\
\hline & Control group & 1.47 & 0.68 & & & \\
\hline & Experimental group & 2.63 & 0.49 & & & \\
\hline ThII) & Control group & 0.97 & 0.41 & & 50 & 0.001 \\
\hline & Experimental group & 9.33 & 0.71 & & -0 & \\
\hline NAMIV & Control group & 5.23 & 0.86 & & & 0.001 \\
\hline & Experimental group & 49.27 & 1.86 & & & \\
\hline & Control group & 23.67 & 2.75 & & Jo & 0.001 \\
\hline
\end{tabular}


Table (1) reports that the mean score of the experimental group was higher than that of the control group in all skills of the lexical test and in the total score of the test. The results also reveal that the mean score of the different lexical skills have been enhanced. The " $t$ " value of the skills ranged between (24.48- 5.03), all of which are statistically significant at (0.001). Whereas, the mean score of the experimental group students in the post administration of the whole test were ( $\{9, r \vee$ ) and the control group were (23.67). The value of " $t$ " of the test was (42.31). Therefore, the results pointed to that there is a statistically significant difference at $(0.001)$ between the mean score of the experimental group and that of the control group in all skills in favor of the experimental group.

\section{Results of hypothesis 2:}

The second hypothesis stated that "there is a statistically significant difference at $\leq(0.05)$ level between the mean score of students of the experimental group on the pre and post lexical skills test in favor of the posttest". To verify this hypothesis, Paired samples t-test was used to calculate the difference between the experimental group performance on the pre and that on the post application of the lexical test. The results are presented here in table (2)

The results in table (2) indicate that the mean score of the experimental group was higher in the post administration of the lexical test than that of the pre administration of the test. 
JRCIET

Vol. 7, No. 3

July 2021

Table (2): Comparing the Experimental Group Performance on the Pre and Post Administration of the Lexical Test

\begin{tabular}{|c|c|c|c|c|c|c|}
\hline \multirow[b]{2}{*}{ Lexical Skills } & \multirow[b]{2}{*}{ Test } & \multirow[b]{2}{*}{ Mean } & \multirow[b]{2}{*}{ SD } & \multicolumn{3}{|c|}{ t-test } \\
\hline & & & & $\mathrm{t}$ & DF & P-value \\
\hline \multirow{2}{*}{ Skill1 } & Pre-test & 1.23 & 0.68 & \multirow{2}{*}{21.63} & \multirow{2}{*}{29} & \multirow{2}{*}{0.001} \\
\hline & Post-test & 4.57 & 0.50 & & & \\
\hline \multirow{2}{*}{ Skill2 } & Pre-test & 3.10 & 1.21 & \multirow{2}{*}{23.01} & \multirow{2}{*}{29} & \multirow{2}{*}{0.001} \\
\hline & Post-test & 9.03 & 0.76 & & & \\
\hline \multirow{2}{*}{ Skill3 } & Pre-test & 1.77 & 0.77 & \multirow{2}{*}{15.22} & \multirow{2}{*}{29} & \multirow{2}{*}{0.001} \\
\hline & Post-test & 4.60 & 0.50 & & & \\
\hline \multirow{2}{*}{ Skill4 } & Pre-test & 1.67 & 0.84 & \multirow{2}{*}{15.84} & \multirow{2}{*}{29} & \multirow{2}{*}{0.001} \\
\hline & Post-test & 4.33 & 0.66 & & & \\
\hline \multirow{2}{*}{ Skill5 } & Pre-test & 0.53 & 0.51 & \multirow{2}{*}{9.87} & \multirow{2}{*}{29} & \multirow{2}{*}{0.001} \\
\hline & Post-test & 1.70 & 0.47 & & & \\
\hline \multirow{2}{*}{ Skill6 } & Pre-test & 0.63 & 0.56 & \multirow{2}{*}{25.18} & \multirow{2}{*}{29} & \multirow{2}{*}{0.001} \\
\hline & Post-test & 4.47 & 0.68 & & & \\
\hline \multirow{2}{*}{ Skill7 } & Pre-test & 1.43 & 0.73 & \multirow{2}{*}{13.61} & \multirow{2}{*}{29} & \multirow{2}{*}{0.001} \\
\hline & Post-test & 4.23 & 0.82 & & & \\
\hline \multirow{2}{*}{ Skill8 } & Pre-test & 1.53 & 0.94 & & & \\
\hline & Post-test & 4.37 & 0.61 & 10.10 & 29 & 0.001 \\
\hline $\mathbf{S}$ & Pre-test & 1.37 & 0.76 & 020 & 20 & 1 \\
\hline SKIIY & Post-test & 2.63 & 0.49 & 7.00 & 29 & 0.001 \\
\hline Clzillo & Pre-test & 1.50 & 0.94 & 2477 & & 1 \\
\hline DКाIIV & Post-test & 9.33 & 0.71 & 04.11 & 29 & 0.001 \\
\hline & Pre-test & 14.77 & 2.49 & & & \\
\hline Lexicat test & Post-test & 49.27 & 1.86 & 50.00 & 27 & 0.001 \\
\hline
\end{tabular}


The value of the " $\mathrm{t}$ " test was (58.80) which point to a statistically significant difference at $(0.001)$ between the mean score of the experimental group students on the prepost administration of lexical test in all skills in favor of the post administration.

\section{Results of hypothesis 3:}

The third hypothesis stated that "there is a statistically significant difference at $\leq(0.05)$ level between the mean score of the experimental group and that of the control group on the post administration of the grammar test in favor of the experimental group". The researcher used Independent samples t-test to verify this hypothesis. Table (3) shows the results:

Table (3): Comparing the Performance of the Experimental and the Control Groups on the Post Administration of the Grammar Test

\begin{tabular}{|c|c|c|c|c|c|c|}
\hline \multirow{2}{*}{ Grammar Skills } & \multirow{2}{*}{ Study groups } & \multirow{2}{*}{ Mean } & \multirow{2}{*}{ SD } & \multicolumn{3}{|c|}{ t-test } \\
\hline & & & & $\mathbf{t}$ & DF $\mid$ & P-value \\
\hline \multirow{2}{*}{$\begin{array}{c}\text { Identify parts of speech } \\
\text { in sentences }\end{array}$} & Experimental & 18.13 & 0.90 & \multirow{2}{*}{25.09} & \multirow{2}{*}{\multicolumn{2}{|c|}{\begin{tabular}{l|l}
58 & 0.001
\end{tabular}}} \\
\hline & Control group & 11.40 & 1.16 & & & \\
\hline \multirow{2}{*}{$\begin{array}{c}\text { Identify the } \\
\text { grammatical units of } \\
\text { English, sentences }\end{array}$} & Experimental & 15.07 & 0.83 & \multirow{2}{*}{\multicolumn{2}{|c|}{24.1858}} & \multirow[b]{2}{*}{0.001} \\
\hline & Control group & 9.43 & 0.97 & & & \\
\hline \multirow{2}{*}{ Grammar test } & Experimental & 33.20 & 1.16 & \multirow{2}{*}{\multicolumn{2}{|c|}{$|33.44| 58$}} & \multirow[b]{2}{*}{0.001} \\
\hline & Control group & 20.83 & 1.66 & & & \\
\hline
\end{tabular}


The mean score of the experimental group was higher than that of the control group in all skills of the grammar test and in the total score of the test as it was reported by table (3). The results also reveal that the mean score of the individual grammar skills have been enhanced. The mean score of the experimental group students in the post administration of the whole test were (33.20) and the control groups were (20.83). The value of " $t$ " of the test was (33.44). The results pointed to a statistically significant difference at (0.001) between the mean score of the experimental group and that of the control group in all skills in favor of the experimental group.

\section{Results of hypothesis 4:}

The fourth hypothesis stated that "there is a statistically significant difference at $\leq(0.05)$ level between the mean score of students of the experimental group on the pre and post grammar skills test in favor of the posttest". To verify this hypothesis, the Paired samples t-test was used to calculate the results presented in table (4)

Table (4) indicates that the mean score of the experimental group was higher in the post administration of the grammar test than that of the pre administration of the test. The value of " $t$ " test was (73.47) which refer to a statistically significant difference at $(0.001)$ between the mean score of the experimental group students on the prepost administration of grammar test in all skills in favor of the post administration. 
Table (4): Comparing the Experimental Group Performance on the Pre and Post Administration of the Grammar Test

\begin{tabular}{|c|c|c|c|c|c|c|}
\hline \multirow{2}{*}{ Grammar Skills } & \multirow{2}{*}{ Test } & \multirow{2}{*}{ Mean } & \multirow{2}{*}{ SD } & \multicolumn{3}{|c|}{ t-test } \\
\hline & & & & $\mathbf{t}$ & DF & P-value \\
\hline \multirow{2}{*}{$\begin{array}{c}\text { Identify parts of speech in } \\
\text { sentences }\end{array}$} & $\begin{array}{l}\text { Pre- } \\
\text { test }\end{array}$ & 6.27 & 0.94 & \multirow{2}{*}{44.64} & \multirow{2}{*}{29} & \multirow{2}{*}{0.001} \\
\hline & $\begin{array}{l}\text { Post- } \\
\text { test }\end{array}$ & 18.13 & 0.90 & & & \\
\hline \multirow{2}{*}{$\begin{array}{l}\text { Identify the grammatical } \\
\text { units of English, sentences } \\
\text { structure and sentence } \\
\text { concepts }\end{array}$} & $\begin{array}{l}\text { Pre- } \\
\text { test }\end{array}$ & 4.93 & 0.69 & \multirow{2}{*}{50.19} & \multirow{2}{*}{5829} & \multirow{2}{*}{0.001} \\
\hline & $\begin{array}{l}\text { Post- } \\
\text { test }\end{array}$ & 15.07 & 0.83 & & & \\
\hline \multirow{2}{*}{ Grammar test } & $\begin{array}{l}\text { Pre- } \\
\text { test }\end{array}$ & 11.20 & 1.16 & \multirow{2}{*}{73.47} & \multirow{2}{*}{29} & \multirow{2}{*}{0.001} \\
\hline & $\begin{array}{c}\text { Post- } \\
\text { test }\end{array}$ & 33.20 & 1.16 & & & \\
\hline
\end{tabular}

\section{Results of hypothesis 5:}

The fifth hypothesis stated that "there is a statistically significant difference at $\leq(0.05)$ level between the mean score of the experimental group and that of the control group on the post administration of the EFL writing test in favor of the experimental group". The researcher used Independent samples t-test to verify this hypothesis. Table (5) illustrates the results: 
Table (5): Comparing the Writing Performance of the Two Groups on the post Administration of the EFL writing test

\begin{tabular}{|c|c|c|c|c|c|c|}
\hline \multirow{2}{*}{ Skills } & \multirow{2}{*}{ Study groups } & \multirow{2}{*}{ Mean } & \multirow{2}{*}{ SD } & \multicolumn{3}{|c|}{ t-test } \\
\hline & & & & $\mathbf{t}$ & DF & P-value \\
\hline \multirow{2}{*}{ Pre-writing } & Experimental group & 24.33 & 1.54 & \multirow{2}{*}{18.27} & \multirow{2}{*}{58} & \multirow{2}{*}{0.001} \\
\hline & Control group & 16.03 & 1.96 & & & \\
\hline \multirow{2}{*}{ During-writing } & Experimental group & 11.80 & 1.49 & \multirow{2}{*}{11.49} & \multirow{2}{*}{58} & \multirow{2}{*}{0.001} \\
\hline & Control group & 7.10 & 1.67 & & & \\
\hline \multirow{2}{*}{ Post-writing } & Experimental group & 10.53 & 0.68 & \multirow{2}{*}{\multicolumn{2}{|c|}{$10.37 \mid 58$}} & \multirow{2}{*}{0.001} \\
\hline & Control group & 6.27 & 2.15 & & & \\
\hline \multirow{2}{*}{ Writing test } & Experimental group & 46.67 & 2.38 & \multirow{2}{*}{26.77} & & \multirow{2}{*}{0.001} \\
\hline & Control group & 29.40 & 2.61 & & & \\
\hline
\end{tabular}

The results in table (5) indicate that the mean score of the experimental group was higher than that of the control group in all skills of the EFL writing test and in the total score of the test. It is worth noting that the mean score of the experimental group students in the whole test were (46.67) compared to the control group were (29.40). The value of " $t$ " of the test was (26.77). The results pointed to a statistically significant difference at (0.001) between the mean score of the experimental group and that of the control group in all skills in favor of the experimental group. These results mean that using the program based on DDL was effective in enhancing lexico-grammatical performance skills and this is reflected on the performance of the students in the EFL writing. 


\section{Results of hypothesis 6:}

The sixth hypothesis stated that "there is a statistically significant difference at $\leq(0.05)$ level between the mean score of students of the experimental group on the pre and post EFL writing skills test in favor of the posttest". The results are presented in table (6)

Table (6): Comparing the Experimental Group Performance on the Pre and Post Administration of the Writing Test

\begin{tabular}{|c|c|c|c|c|c|c|}
\hline \multirow{2}{*}{ EFL Writing Skills } & \multirow{2}{*}{ Test } & \multirow{2}{*}{ Mean } & \multirow{2}{*}{ SD } & \multicolumn{3}{|c|}{ t-test } \\
\hline & & & & $t$ & DF & P-value \\
\hline \multirow{2}{*}{ Pre-writing } & Pre-test & 9.23 & 3.08 & \multirow{2}{*}{25.94} & \multirow{2}{*}{29} & \multirow{2}{*}{0.001} \\
\hline & Post-test & 24.33 & 1.54 & & & \\
\hline \multirow{2}{*}{ During-writing } & Pre-test & 4.33 & 2.01 & \multirow{2}{*}{18.14} & \multirow{2}{*}{29} & \multirow{2}{*}{0.001} \\
\hline & Post-test & 11.80 & 1.49 & & & \\
\hline \multirow{2}{*}{ Post-writing } & Pre-test & 3.20 & 1.10 & \multirow{2}{*}{32.36} & \multirow{2}{*}{29} & \multirow{2}{*}{0.001} \\
\hline & \begin{tabular}{|l|} 
Post-test \\
\end{tabular} & 10.53 & 0.68 & & & \\
\hline \multirow{2}{*}{ Writing test } & Pre-test & 16.77 & 2.92 & \multirow{2}{*}{49.40} & \multirow{2}{*}{29} & \multirow{2}{*}{0.001} \\
\hline & \begin{tabular}{|l|} 
Post-test \\
\end{tabular} & 46.67 & 2.38 & & & \\
\hline
\end{tabular}

Results in table (6) show that the experimental group performance in the post administration of the writing test was better than that of the pre-administration. The mean score on the post one was (46.67) compared to (16.77) in the pre administration.

Results and discussion related to the effect size of DDL based program

The seventh hypothesis stated that "using DDL achieves effect size at $(\leq 0.14)$ level for improving student teachers' lexico-grammatical performance skills in EFL writing". 
To calculate the effect size of the independent variable (teaching using a program based on DDL) on the dependent variable (lexico-grammatical performance skills in EFL writing), the ( $\eta 2)$ value was calculated as presented in table (7):

Table (7): the effect size of using a program based on DDL on the experimental group lexico-grammatical performance skills in EFL writing

\begin{tabular}{|c|c|c|c|c|}
\hline Dependent Variables & T & DF & Eta square $\left(\eta^{2}\right)$ & Effect size \\
\hline Lexical skills & 58.80 & 29 & 0.992 & Large \\
\hline Grammar skills & 73.47 & 29 & 0.995 & Large \\
\hline Writing skills & 49.40 & 29 & 0.988 & Large \\
\hline
\end{tabular}

Results in table (7) indicate that the effect size ( $\eta 2)$ of the program based on DDL on the lexico-grammatical performance skills in EFL writing was arranged respectively (0.992-0.995-0.988). This illustrates the effectiveness of using a program based on DDL in improving the experimental group student teachers' lexicogrammatical performance skills in EFL writing.

\section{Results of hypothesis 8:}

The eighth hypothesis stated that "developing lexicogrammatical performance skills has an impact on the development of EFL writing performance of the experimental group students". To test this hypothesis, the researcher used the multiple linear regression method. The results are shown in the following table: 
Table (8): the effect size of developing lexico-grammatical performance skills on the development of EFL writing performance on the experimental group students

\begin{tabular}{|c|c|c|c|c|c|}
\hline & $\begin{array}{c}\text { Sum of } \\
\text { Squares }\end{array}$ & df & $\begin{array}{c}\text { Mean } \\
\text { Square }\end{array}$ & $\mathbf{F}$ & $\begin{array}{c}\text { P- } \\
\text { value }\end{array}$ \\
\hline Regression & 81.92 & 2 & 40.96 & \multirow{3}{*}{13.37} & \multirow{3}{*}{0.001} \\
\hline Residual & 82.74 & 27 & 3.06 & & \\
\hline Total & 164.67 & 29 & & & \\
\hline
\end{tabular}

Table (8) reveals that there is a good effect for the lexico-grammatical performance skills on the performance of student teachers' EFL writing skills on the experimental group. The " $\mathrm{f}$ " value was (13.37) and statistically significant at $(0.001)$. The results indicate the regression coefficients and its significance as shown in the following table:

Table (9): the regression coefficients and its significance

\begin{tabular}{|c|c|c|c|}
\hline & B & t & P-value \\
\hline (Constant) & 3.04 & 0.31 & 0.755 \\
\hline Lexical skills & 0.23 & 3.55 & 0.001 \\
\hline Grammar skill & 0.97 & 3.45 & 0.002 \\
\hline
\end{tabular}

Table (9) reveals the values of regression model and its significance. The results illustrate that all the values were statistically significant in the lexico-grammatical 
performance skills. The performance of EFL writing can be predicted from the following formula: EFL Writing Performance $=(0.23)$ Lexical Skills $+(0.97)$ Grammar Skills + (3.04) From Table (8 \& 9)

\section{Discussion of the Research Results}

The results revealed that most of the participants evidently had a positive attitude towards the DDL approach as it is considered to be a useful resource to acquire lexicogrammatical in order to improve EFL writing. In particular, almost all of the participants thought that their lexicogrammatical performance skills was enhanced by applying the program through the DDL approach as it helped them understand the lesson and be able to apply lexicogrammatical skills in the real context and in the writing process.

The research revealed that DDL can be an effective tool to learn lexico-grammatical performance skills and this improvement is reflected on student teachers' performance in the EFL writing especially on the advanced level of EFL acquisition. This research is supported by literature (Noguera-Díaz \& Pérez-Paredes, 2020; Römer, Viviana \& Eric, 2020 ; Qoura, 2018; Ali, 2016) that establish evidence that the DDL approach has several advantages for language learners. For example learners take an active role in working through an extensive language material independently which consolidate their anatomy. Exposure to authentic language input make learners more sensitive towards language variation. In addition, discovery learning 
is enhanced because using data-driven is an inquiry-based activity and opposes explicit instruction by the teacher. Finally, using data-driven learning access such as BNC, COCA and CANCODE helped learners to make their own judgment about the meaning of lexico-grammatical items.

Results of the current research are in line with those of (Noguera-Díaz \& Pérez-Paredes, 2020; Römer, Viviana \& Eric, 2020; Qoura, 2018; Mao et al, 2018; Y1lmaz, 2017; Barabadi \& Khajavi, 2017; Nugraha et al, 2017; Mizumoto \& Chujo, 2016; Ali, 2016; Luo, 2016; Sepehri, 2015; Ucar \& Yükselir, 2015; Sah, 2015; Yoon \& Jo, 2014 which reported the effectiveness of program DDL based program on developing learners' lexico-grammatical performance skills in EFL writing.

During the implementation of the DDL program the researcher noticed that the results of the current research indicated the verification of the previous hypothesis and the high value of the experimental treatment's effect size upon the overall lexico-grammatical performance skills in EFL writing. Some student teachers of the experimental group expressed their positive attitudes towards data-driven learning based program.

\section{Conclusions}

A number of conclusions were derived from the current research.

- Applying DDL helps student teachers' to feel more confident to formulate their own findings. It proved suitability for different learners' styles especially 
kinesthetic. It has a positive effect on student teachers' through using hands on DDL and hands off DDL.

- Applying DDL approach in learning showed that the more students are exposed to authentic data, the less possibility and the negative transfer occurs as authenticity reduces negative transfer and brings unnatural English to the minimum. Also, DDL approach helped to reduce the gap of studying English as a foreign language in Egypt where students are often exposed to pedagogical pre-fabricated data rather than authentic data.

- Using computer based DDL and paper-based DDL approach in teaching lexico-grammatical performance skills gives students a chance to notice and build up rules as it enhances their understanding of lexicogrammatical in EFL writing as a description of the actual language.

- DDL program proved that it is more suitable for student teachers' level because of the huge amount of data the students need to be exposed to. Hence, it is unsuitable for lower level learners.

\section{References}

- Abu- Shawish, J.(2009). Analysis and Assessment of Palestinian EFL Majors' Written English [Doctoral dissertation, University of Science and Technology- Sudan]. https://www.researchgate.net/ publication/314643843

- Ali, H. (2016). The effectiveness of using corpus approach in developing writing skills and reducing writing anxiety among EFL student teachers [Doctoral dissertation, University of BenhaEgypt]. 
- Al-Khairy, M. (2013). Saudi English-major undergraduates' academic writing problems: A taif university perspective. English Language Teaching, 6 (6), 1-12.

- Almansour, N., \&Alshorman,R.(2014).The Effect of an extensive program on the writing performance of Saudi EFL university students. International Journal of Linguistics, 6 (10), 247-264.

- Aşık, A., Vural, A., \& Akpınar, K. (2016). Lexical awareness and development through data driven learning: Attitudes and beliefs of EFL learners. Journal of Education and Training Studies, 4(3), 87-96.

- Bahloul, M. (2007). Spelling errors of Arab learners: Evidence of intergraphic mapping. In: C. Combe \& L. Barlow (Eds.), Language Teacher Research in the Middle East (41-51). Mattoon, Ill: United Graphics.

- Barabadi, E \& Khajavi, Y .(2017). The effect of data-driven approach to teaching vocabulary on Iranian students' learning of English vocabulary. Cogent Education, 4, 1-13.

- Boulton, A. (2009b). Testing the limits of data-driven learning: language proficiency and training. ReCALL, 21, 37-53.

- Bruning, R., \&Horn,C.(2000). Developing motivation to write. Educational Psychologist. Cambridge, Cambridge University Press.

- Chambers, A. (2010). "What is data-driven learning?" In A. O'Keeffe \& M. McCarthy (eds.), The Routledge Handbook of Corpus Linguistics (345-358). London: Routledge.

- Davies, M. (2008). The Corpus of Contemporary American English (COCA): 410+ million words, 1990-present. Retrieved January 13, 2020, from http://www.americancorpus.org.

- Flowerdew, J. (2009). Corpora in language teaching. In M. H. Long \& C. J. Doughty (Eds.), The Handbook of Language Teaching (pp. 327-350). Oxford, UK: Wiley-Blackwell.

- Flowerdew, L. (2009). Applying corpus linguistics to pedagogy: A critical evaluation. International Journal of Corpus Linguistics, 14(3), 393-417. https://doi: 10.1075/ijcl.14.3.05flo 
- Guan, X. (2013). A study on the application of Data-driven learning in vocabulary teaching and learning in China"s EFL class. Journal of Language Teaching and Research, 4 (1), 105112.

- Johns, T. (1991). Should you be persuaded: Two examples of data-driven learning. In T. Johns \& P. King (Eds.), Classroom concordancing (pp. 1-16). Cambridge: Cambridge University Press.

- Keong, C. \& Mussa, H. (2015). Academic writing difficulties of Iraqi postgraduate students in Malaysia. International Journal of Education and Research5 (3) 301-351.

- Khamis, M. (2019). A suggested program based on blending two strategies (graphic organizers and think-aloud protocols) on developing second year secondary stage students' EFL writing skills [Doctoral dissertation, University of Damietta-Egypt].

- Koda, K. (2000). Cross-linguistic variations in L2 morphological awareness. Applied Psycholinguistics, 21, 297-320. http://dx.doi.org/10.1017/S0142716400003015

- Luo, Q. (2016). The effects of data-driven learning activities on EFL learners' writing development. Springer Open, 5(1255), 113. https://doi.org/10.1186/s40064-016-2935-5

- Mao, L., Liu, Y. \& Zhang, M. (2018). The Effectiveness of College Student English Writing Teaching Based on Data-Driven Learning. Educational Sciences: Theory \& Practice, 18(5), 11601169. http:// doi.org/10.12738/estp.2018.5.017

- Megaiab, M. (2014, May 6-8). The English writing competence of the students of an Indonesian senior high school [Conference Session]. In Proceedings of the West East Institute (WEI) Academic Conference, Indonesia.

- Mizumoto, A., Chujo, K., \& Yokota, K. (2016). Development of a scale to measure learners' perceived preferences and benefits of data-driven learning. ReCALL, 28, 227-246. http://doi:10.1017/ $\underline{\mathrm{S} 0958344015000208}$ 
- Mostafa, H., Dadour, E., \& Qoura, A. (2019). Using a Computerbased Scaffolding Strategy to Enhance EFL Preparatory Stage Students' Reading Skills and Self-Regulation. Journal of Research in Curriculum Instruction and Educational Technology, 5(1), 111134.

- Mourtaga,K.(2010,October 14-15 ). Poor Writing in English .A case of the Palestinian EFL learners in Gaza Strip [Conference]. First National Conference, Gaza, Palestine. http://scholar.google. com/citations? user=2J2EsiAAAAAJ\&hl=en

- Nation, I. (2001). Learning vocabulary in another language. Cambrindge: Cambridge University Press.

- Noguera-Díaz, Y., \& Pérez-Paredes, P. (2020). Teaching acronyms to the military: A paper-based DDL approach. Research in Corpus Linguistics, 8(2),1-27. https://doi.org/10.32714/ ricl. $\underline{08.02 .01}$

- Nugraha, S., Miftakh, F., \& Wachyudi, K.(2017).Teaching Grammar Through Data-Driven Learning (DDL) Approach. Advances in Social Science, Education and Humanities Research (ASSEHR), 82,300-303

- Qoura,Y. (2018). The Impact of Corpus-Based Program on Enhancing the EFL Writing Skills and Self-Autonomy of Student Teachers at the Faculties of Education [Unpublished doctoral dissertation]. University of Mansoura- Egypt.

- Rao, T. (2007). Training in brainstorming and developing writing skills. ELT Journal, 61 (2), 100-106.

- Römer, U., Viviana, C., \& Eric F. (2020). Advances in Corpusbased Research on Academic Writing. Effects of Discipline, Register, and Writer Expertise. Amsterdam: John Benjamins.

- Sah.P. (2015). An Investigation into the Relative Effectiveness of data-driven Learning (DDL) with Integration in to PPP and III. The Journal of Teaching English for Specific and Academic Purposes 3 (2) 347-366

- Sepehri, M. (2015). The effects of data-driven learning on Iranian EFL learners' writing skills development [Doctoral dissertation, 
University of Birmingham]. http://etheses.bham.ac.uk/6267/1/ Sepehri1 5PhD_Redacted.pdf

- Ucar, S., \& Yükselir, C. (2015). The effect of corpus-based activities on verb-noun collocations in EFL classes. Turkish Online Journal of Educational Technology - TOJET, 14 (2), 195205.

- Yilmaz, M. (2017) .The Effect of Data-driven Learning on EFL Students" Acquisition of Lexico-grammatical Patterns in EFL Writing. Eurasian Journal of Applied Linguistics 3(2), 75-88

- Yoon, H., \& Jo, J. (2014). Direct and indirect access to corpora: An exploratory case study comparing students' error correction and learning strategy use in L2 writing. Language Learning and Technology, 18(1), 96-117. 